\title{
Inclusão e autismo: contribuições da Psicopedagogia
}

Merianne da Silva Lima ${ }^{1}$

Antônio Eugênio Cunha é doutor em Educação, psicopedagogo da educação básica, professor do ensino superior e pesquisador na área educacional. Atua na educação de alunos com dificuldades de aprendizagem e autismo. Esta obra traz um olhar psicopedagógico sobre alunos com o Transtorno do Espectro Autista (TEA), enfatizando a importância de um currículo centrado em práticas pedagógicas que favoreçam a aprendizagem e a inclusão escolar e social do aluno com autismo, num esforço coletivo, em detrimento das concepções errôneas do déficit e da patologização.

Para responder à questão acerca da definição do autismo, no primeiro capítulo, intitulado Para conhecer e identificar o autismo, o autor esclarece que o Transtorno do Espectro Autista (TEA) apresenta níveis diferentes de gravidade, que está ligado a outros sintomas que surgem ainda na infância. É uma síndrome tão complexa que, apesar de muitos estudos, não há um padrão fixo que determine um diagnóstico preciso, sendo que os sintomas variam de uma criança para outra, dificultando, dessa maneira, determinar um perfil único. Contudo, o autor caracteriza que "[...] o autismo compreende a observação de um conjunto de comportamentos agrupados em uma tríade principal: comprometimento na comunicação, dificuldades na interação social e atividades restrito-repetitivas" (p. 20). E, a partir dessa tríade comportamental, faz uma breve descrição do que seria um comportamento autístico, listando uma série de sintomas que, se forem percebidos precocemente nas crianças, auxiliará no reconhecimento do TEA.

Para responder a interrogativa que intitula o segundo capítulo, O que o educador precisa saber?, Cunha destaca como ocorre o processo de aprendizagem de uma criança típica e de uma criança com autismo, enfatiza a importância do processo educativo do aluno com autismo, independentemente da severidade, acontecer por meio do atendimento educacional especializado individualmente na sala de recursos e na sala de ensino comum, favorecendo a inclusão destes. Ainda neste capítulo, o autor esclarece que o mais importante para um aluno com autismo, inicialmente, é a aquisição de suas habilidades sociais e sua autonomia, e só depois o desenvolvimento acadêmico. Para isso, pontua uma série de aspectos comuns ao autismo acompanhados de sugestões pedagógicas, a saber: capacidade sensorial, capacidade espacial, capacidade de simbolizar, subjetividade, linguagem, cognição, hiperatividade, estereotipias, psicomotricidade, socialização e afeto.

1 Mestranda em Educação (PPGE/UFAM). Universidade Federal do Amazonas. E-mail: lima_parintins@hotmail.com. ORCID iD: https://orcid.org/0000-0001-6272-4774. 
Nos capítulos terceiro e quarto, intitulados, respectivamente, O que construir com o aprendente autista? e Um currículo com atividades funcionais, Cunha revela-nos que, para o processo de aprendizagem ser efetivo se faz necessário um currículo que foque em práticas pedagógicas voltadas para o aprendente, para o ser humano, e não, no déficit, nas dificuldades. Salienta, ainda, que está no aprendente a concretização da educação, a partir de estratégias que transformem essas dificuldades em vontade de aprender e construir, dando-lhe autonomia, e que estas atividades devem ter caráter terapêutico, afetivo, social e pedagógico. Segue salientando que um currículo funcional deve estar em sincronia com a escola e a família, e o primeiro passo para se construir esse currículo para o aprendente autista é a avaliação, para descobrir quais habilidades precisam ser desenvolvidas. Apesar de não ser regra, sugere alguns parâmetros que podem nortear o trabalho do professor - que vão desde materiais pedagógicos, alimentação, reforçadores positivos, até técnicas de educação comportamental, como o método TEACCH (Tratamento e educação para autistas e crianças com distúrbios correlatos da comunicação), o ABA (Análise aplicada ao comportamento) e o PECS (Sistema de comunicação mediante a troca de figuras) que podem ser realizadas tanto na escola quanto na família.

No quinto capítulo, intitulado Comunicação, memória e atenção, pontuam-se os vários processos que precisam ser desenvolvidos com aprendentes autistas, com destaque para a concentração, a coordenação motora, a comunicação e a linguagem. Diferente da criança típica, o aluno autista precisa adquirir habilidades comunicativas através da compreensão da linguagem para a sua utilização, habilidades de letramento, habilidades com diferentes meios de comunicação e a capacidade para superar a frustração e a irritabilidade que podem advir das dificuldades de comunicação, além do estímulo da memória visual e atenção, ou seja, se atrair o aluno para o que gosta, este se concentrará nas atividades.

No sexto capítulo, intitulado Escola e família, destaca-se a importância da articulação da família, da escola e outros profissionais com diferentes formações para o tratamento e intervenção do aluno com autismo; que o grande desafio para o sucesso das intervenções e do processo educativo desse público é a consonância da escola e família nessas ações de aprendizagem, ou seja, esses dois ambientes, apesar de diferentes, devem ser concordes em objetivos e práticas educativas mediadas pelo amor.

Intitulados, respectivamente, Professor, escola e inclusão e A contribuição da Psicopedagogia, nos capítulos sétimo e oitavo, Cunha lembra que foi a partir da LDB no 9394/96 que a Educação Especial ganhou maior destaque, que, apesar de apresentar apenas três artigos $(58,59,60)$, se for cumprido integralmente, o Brasil será uma referência mundial nesse tema. Contudo há uma série de questões que devem ser consideradas para uma instituição de ensino alcançar seus objetivos de inclusão, como um ambiente escolar favorável, aliado à formação do educador, pois é extremamente importante que ele tenha condições de exercer sua função "com a inclusão e na inclusão". No que se refere às contribuições da Psicopedagogia, o autor destaca que não se trata apenas de agregar a Psicologia à Pedagogia na identificação de dificuldades de aprendizagem, mas, sobretudo, a incumbência de propor alternativas a partir de um olhar interdisciplinar e multidisciplinar.

Para finalizar, no último capítulo, intitulado $\mathrm{Na}$ inclusão, uma palavra de amor, o autor discorre sobre a importância do ambiente educativo e a atuação do professor para atender o novo modelo pedagógico advindo da pós-modernidade, em detrimento do atual modelo, que, através dos anos, instalou-se na escola. Ressalta ainda que a questão não seria o desprezar tudo que se construiu ao longo da história da educação, mas que a grande questão a que se propõe é que a aprendizagem seja mediada por meio do amor, do afeto, pois "[...] é para o amor que educamos, por ser o amor nossa maior inspiração" (p. 118).

Os nove capítulos do livro de Eugênio Cunha trazem à luz as discussões acerca do Transtorno do Espectro Autista (TEA). E, quando se fala em alunos com autismo, não faltam indagações do tipo: O que devo fazer? Como ensinar? Ele(a) vai aprender? E um dos aspectos positivos da obra 
é a contribuição da Psicopedagogia, com várias sugestões práticas educativas para uma efetiva inclusão escolar e social do aluno com autismo, além das reflexões apresentadas sobre a díade escola e família para o processo de inclusão do aprendente autista.

Contudo, um ponto do livro que poderia merecer mais atenção é o capítulo quatro (Um currículo com atividades funcionais), pois acredita-se que as sugestões apresentadas de materiais pedagógicos aos professores deveriam ser direcionadas de acordo com o grau de severidade do autismo. Também poderia ser dado um destaque maior aos métodos para intervenção comportamental para autistas (TEACCH, ABA, PECS, SON-RISE).

Apesar da complexidade e de não poder esgotar as reflexões do tema em questão, esta obra apresenta inúmeras discussões acerca da educação especial na perspectiva inclusiva. Por isso, o livro em estudo é recomendado para indivíduos com interesse no assunto, em particular, para estudantes de pedagogia, licenciaturas, professores, pedagogos e a família que tenha pessoa com TEA, por acreditar que a verdadeira inclusão se dá por meio da atuação coletiva.

\section{Referência}

CUNHA, Antônio Eugênio. Autismo e Inclusão: psicopedagogia e práticas educativas na escola e na família. 8. ed. Rio de Janeiro: Wak Ed., 2019. [140p.: $21 \mathrm{~cm}]$.

Data de submissão: 03/02/2021

Data de aceite: $14 / 04 / 2021$ 